\title{
Program of Cultural Heritage and Museum Studies in Tourism Education: Case Study of a U.S Program and Potentials of Application in Egypt* Marwa Abd el-Meguid el-Kady.
}

Faculty of Tourism and Hotels, Alexandria University

\begin{abstract}
Museum and cultural heritage studies has become an important trend in various educational institutions and universities all over the world as an essential mean of emphasizing the identity of nations on one hand, and for the economic and cultural benefits gained by protecting it on the other. The main aim of this study is to clarify how such program can be of the highest priorities in Egyptian tourism education today due to the vital role played by cultural heritage in tourism in Egypt. Regarding the fact that such programs are still under development in Egypt, it is important that the study should take a model of an already existing program of this type as a case study to examine its potentials as a standard that can be followed. I was able to achieve the goals of this study and conduct this research as I had the opportunity to study the master program of Heritage and Museum Studies in the University of Denver (DU), Colorado, U.S on ground as a Fulbright award granted visiting scholar in the academic year 2018/2019. The research therefore aims at studying the importance of such a program and how it benefits students in terms of academic outcomes in general and how museum studies form a very important part of it. The research uses the methodology of "case study" of the program of the University of Denver, participant observation of the major components of the program in classrooms or in field; and the "analytical study" of its curricula, courses, syllabi, instructional strategies and internship in seeking to achieve the research objectives to examine the possibilities and potentials of developing a similar program in tourism education in Egypt. The data is collected through semi-structured interviews addressed to students about their perceptions and expectations; and professors of the program about the teaching strategies and methods used in the program. The Research ends with a suggested framework of a program of museum and cultural heritage studies that can be developed in the Egyptian tourism education.
\end{abstract}

Keywords: Cultural Heritage Program, Education, Museum Studies, Curriculum, Internship.

\section{Introduction}

Education has been the primary means for the advancement of the nations. It is also considered the main cornerstone in the concern of preserving and protecting the cultural heritage for future generations. The UNESCO took the lead to preserve the world's cultural and natural heritage through its program, of which education is an essential part (UNESCO, 2005; Keough, 2011). Cultural heritage education approach is teaching and learning about heritage and preserving it with all its various aspects.

through studying history, monuments, human production and practice, including historical sites, museums, galleries, libraries and other cultural institutions; which are very important due to their responsibility for interpreting, preserving and managing the cultural heritage resources (Hansen, 2014; Gruber, 200).

Despite the entire legacy and the treasures of the tangible and intangible cultural heritage of Egypt that play a vital role in tourism, no serious studies have been undertaken to develop special programs for studying this area in the Egyptian tourism education institutions. In fact, the faculty of Tourism and Hotels, Helwan University was pioneer and already developed two programs to

\footnotetext{
* All my gratitude is addressed to professor Dr. Christina Creps the director of the master program of Museum and Heritage Studies for her consistent aid to conduct this research
} 
serve this purpose, but more studies should be made and more programs should be developed in order to suite the importance of the Egyptian cultural heritage and its role in tourism.

The research is divided into three parts: the first studies the importance of the programs of cultural heritage and museum studies in general and in Egypt in particular and how museum studies form a very important part of it; the second part deals with studying a case study of the Museum and Heritage Studies Program (MHS) of the University of Denver, Colorado, U.S using the methodologies of participant observation and analytical studying. The goal is to study all the elements of the program including curricula, courses, syllabi, and internship. In addition, the outcomes of the program are also examined through gatherings from the students through semistructured interviews related to their perceptions and expectations of the program; what benefits do they gain from the program? How do they expect their career to be after finishing the study of this program? And how does the program prepare them to work in heritage and museum fields? Other interviews are undertaken with the professors and teachers of the program to understand the teaching strategies they use and their future visions of the program. The third part of the research examines the potentials of developing a similar program of cultural heritage and museum studies in tourism education in Egypt and its importance providing a suggested framework with all the major components including the educational level, the competencies and internship.

\section{Cultural Heritage Education}

Defining cultural heritage has been an issue of a long debate. Linguistically "heritage" is defined as "that which has been or may be inherited", or "Anything given or received to be a proper possession" (Cormack, 1976). The reason behind this is that individuals' perception of the issue depends on everyone's background; academics, officials, users and non-users of cultural and heritage institutions, each have a different approach (Corsane, 2005). However, generally cultural heritage can simply be defined as the legacy inherited from ancestors, maintained by present generation and has the potentials to pass on to the future descendants (Ocal, 2016; Kearney, 2009).

According to the UNESCO, the 1972 World Heritage Convention, Article 1, cultural heritage can be "monuments: architectural works, works of monumental sculpture and painting, elements or structures of an archaeological nature, inscriptions, cave dwellings and combinations of features, which are of outstanding universal value from the point of view of history, art or science; groups of buildings: groups of separate or connected buildings which, because of their architecture, their homogeneity or their place in the landscape, are of outstanding universal value from the point of view of history, art or science; and sites: works of man or the combined works of nature and man, and areas including archaeological sites which are of outstanding universal value from the historical, aesthetic, ethnological or anthropological point of view" (UNESCO, 1972). In addition, the World Conference in Mexico City on Cultural Policies that was held in 1982 defined the cultural heritage of a people that "includes the works of its artists, architects, musicians, writers and scientists and also the work of anonymous artists, expressions of the people's spirituality, and the body of values which give meaning to life. It includes both tangible and intangible works through which the creativity of that people finds expression: languages, rites, beliefs, historic places and monuments, literature, works of art, archives and libraries"(The Contribution of Education to Cultural Development, 1992).

Generally, cultural heritage incorporates two principal categories: tangible and intangible heritages. The former is the physical and material legacy including monuments, historical and archaeological sites, artifacts, manuscripts and etc., which are worthy of preservation (Vecco, 
2010). It can be subdivided into movable and immovable heritage. The movable includes paintings, sculptures, furniture and wall paintings, and the immovable includes historical buildings, monuments and archeological sites (Kurniawan and others, 2011). Intangible cultural heritage on the other hand according to the Basic Texts of the 2003 Convention for the Safeguarding of the Intangible Cultural Heritage of UNESCO, it "means the practices, representations, expressions, knowledge, skills - as well as the instruments, objects, artifacts and cultural spaces associated therewith - that communities, groups and, in some cases, individuals recognize as part of their cultural heritage. This intangible cultural heritage, transmitted from generation to generation, is constantly recreated by communities and groups in response to their environment, their interaction with nature and their history, and provides them with a sense of identity and continuity, thus promoting respect for cultural diversity and human creativity" (UNESCO, 2016, Higginbottom, 2014).

The growing attention to cultural heritage after the 1960s arose as part of the identity crisis and as a defensive reaction to globalization (Gravari-Barbas, 2018). Moreover, the destruction caused by wars and natural catastrophes has created an increasing awareness of the importance of the cultural heritage and the dangers that have threatened its sustainability (UNESCO, 1972). It is a fact that cultural heritage is important for all nations; from the social perception, it represents every nation's unique national identification, authenticity, and identity that have been developed with the passage of time including language, religion, and interpretations of the past (Graham and others, 2005). On the same basis, it influences the society self's perception and relationships with others due to similarities and differences (Buckland, 2013). A good example of the appreciation of one nation's cultural heritage is the declaration of the European Community that the year 2018 is "The European Year of Cultural Heritage" as a kind of appreciation of the European shared resource of cultural heritage (Pozzi and Dagnino, 2018). In addition, "Heritage tourism" has taken its place as a significant sector, as 'heritage' has become a tourism product. For many tourists a general wish to sightsee and become aware of the destination area's heritage is a sufficient motivation for their visit to a heritage attraction (Rodzi and others, 2013). Cultural Heritage is considered today one of the main tourism drivers and one of the main factors of tourism development (Gravari-Barbas, 2018). Therefore, for economic, cultural and social reasons, the cultural heritage should be preserved and nationally promoted (Borissova, 2017).

Since the establishment of the 1972 World Heritage Convention, education has been regarded as an important factor for safeguarding cultural heritage (Pozzi and Dagnino, 2018). Cultural heritage education has been an urge in many academic institutions all over the world, as implementing this type of education is essential to extend the understanding of the development of nations. At the meantime, it can be a tool to extend the student's judgment and critical power which guarantees that future societies will be more aware of the importance of preserving their cultural heritage and take on responsibility for it. This automatically, will prevent destroying, selling parts of the cultural heritage and raise the awareness of the importance of protecting it for future generations (Stone, 2005).

Today, many university programs have been developed to serve aims which in turn intend to strengthen awareness of culture and history, preserve and enhance appreciation for human achievements and values (Šola, 1982; Teather, 1991).

\section{Museum Studies}

Cultural heritage education is so attached to museum studies. A concept from which emerged the term of "heritology" that was introduced by Tomislav Šola based on the word "heritage" which he uses to refer to the comprehensive sense of the museum and its study (Šola, 1982; Teather, 
1991). The use of the word "museum" goes back to the museion that was founded in Alexandria during the Ptolemaic period. But it was only from the beginning of the seventeenth century did the word use to refer to the institutions where valuable objects were collected and exhibited (Latham and Simmons, 2014). Museums in general play many roles including collecting, conserving, classifying, displaying, researching, educating, and delivering messages (Starn, 2005). Therefore, there are various definitions of museums and they have been reformed all the time depending on emerging of different types and functions of museums (Teather, 1991). However, ICOM Statues (International Council of Museum) at the twenty-first general conference in 2007, Article 3 defined a museum as "a non-profit, permanent institution in the service of society and its development, open to the public, which acquires conserves, research, communicates and exhibits the tangible and intangible heritage of humanity and its environment for the purposes of education, study, and enjoyment" (ICOM, 2007; Latham and Simmons, 2014) The important role of the museums was well recognized long time ago; starting from at least the Nineteenth Century, a special attention was drawn to museum professionals and their training. The Louvre Museum School was founded in Paris in 1882 to train museum professionals (Spiess II, 1996). In Britain, museum training started as early as 1894. The University of Brno, Czechoslovakia, established a Chair for Museology in 1919. South America was a pioneer in the field of museum education, or specifically museum training first was Argentina in 1920s, then, Brazil in 1932 had the first university program. At the same time, reports on training personnel for British museums in 1930 led to offer a diploma in museum training, which was run by the Museums Association (Teather, 1991; Simmons, 2006). Museum training programs in universities were also developed in different parts of the world, like in India in 1952. Other university programs were developed also in Australia in 1975 and in Italy in 1984 (Simmons, 2006).

Museum studies in United States began with a focus on undergraduate education. The first formal program started in 1908 at the Pennsylvania Museum's school of Industrial Art (now the Philadelphia College of Art). In 1910, the Fransworth Museum of Wellesley College started a museum program. In 1911, Homer Dill established a minor in museum science for training in exhibit technique at the Museum of Natural History in the State University of Iowa. In 1920s, two other programs were established; one at Harvard University; and the other for museum educators at the Newark Museum. In 1966, the Department of Museum Studies was created at the University of Leicester (Simmons, 2006).

The biggest growth of museum studies programs took place in 1970s due to the increasing of the number of American museums, federal aid to museums, and growing awareness for trained museum professionals. Today, there is a great number of two-year graduate degree museum studies (Teather, 1991; Spiess II, 1996; Williams and Simmons, 2006; Simmons, 2006). Some of these programs are prominent because their courses maintain good balance between discipline and museum practice, strongly supported by the universities that house them, strong faculty and visiting speakers (Spiess II, 1996).

Most of the museum studies programs in United States are master and terminal degree, PhD programs are regarded as oddities, Masters as second-class, terminal degrees. These master programs have been developed since the 60s of the last century (Teather, 1991, 403-404). The museum studies programs tempt to serve courses related to Museology and Museography. At this point, it is necessary to recognize the difference between the two terms Museology and Museography. 
Muselogy is the study of museum and its contents (Latham and Simmons, 2014,) including the processes of collecting and identifying valuable objects, and translating these processes into professional skills (Theather, 1991; Macleod, 2001). The term "museology" was created more than 120 years ago; one of the earliest use of the suffix "ology" was made by J. Graesser in 1885 in the periodical Zeitschrift für Museologie und Antiquitätenkunde. In 1950 Jiří Neustupny defined museology as the "theoretical aspects of museum work" consisting of 'scientific research and collecting, educational activities, conservation, exhibitions, theory and technique". Another attempt was made later in 1958 to define museology at the UNESCO Regional Seminar on Education held at Rio de Janeiro as a "branch of knowledge concerned with the study of the purposes and organization of museums". The museologists of the German Democratic Republic in 1966 defined musology as "composite body of a number of disciplines that are related to a common social institution, the museum". Consequently, for them, museology was an interdisciplinary marginal science which had its own subject and structure, including the theory of museum work, history of museums, and the methodology of collecting, research and exhibition (Teather, 1991).

On the other hand, the traditional English meaning of museography is the description of the contents of the museum. The word has been however used to refer to the practical and applied aspects of the museum processes like using developed techniques in museum to fulfill certain operations (Latham and Simmons, 2014). In 1971, the ICOM Training Unit in conjunction with the University of Leicester crafted a syllabus entitled "Professional Training of Museum Personnel in the World: Actual State of the Problem" offered a definition for museology as "museum science. It has to do with the study of the history and background of museums, their role in the society, specific systems for research, conservation, education, and organization, relationship with the physical environment, and the classification of different kinds of museums", while "museography covers methods and practices in the operation of museums, in all their various aspects" (ICOM Training Unit, 1972).

The museum studies include museology which is the science of arranging museums or the theory and museography which is the descriptive and technical part of the doctrine (Teather, 1991; Williams and Simmons, 2006). In other words, museum studies are a broad interdisciplinary field that embrace theory (museology) and practice (museography) (Latham and Simmons, 2014). The combination of the museum processes and museum skills frame the field of Museum Studies (Teather, 1991) (fig.1).

Fig. 1 Components of a Museum Studies Program

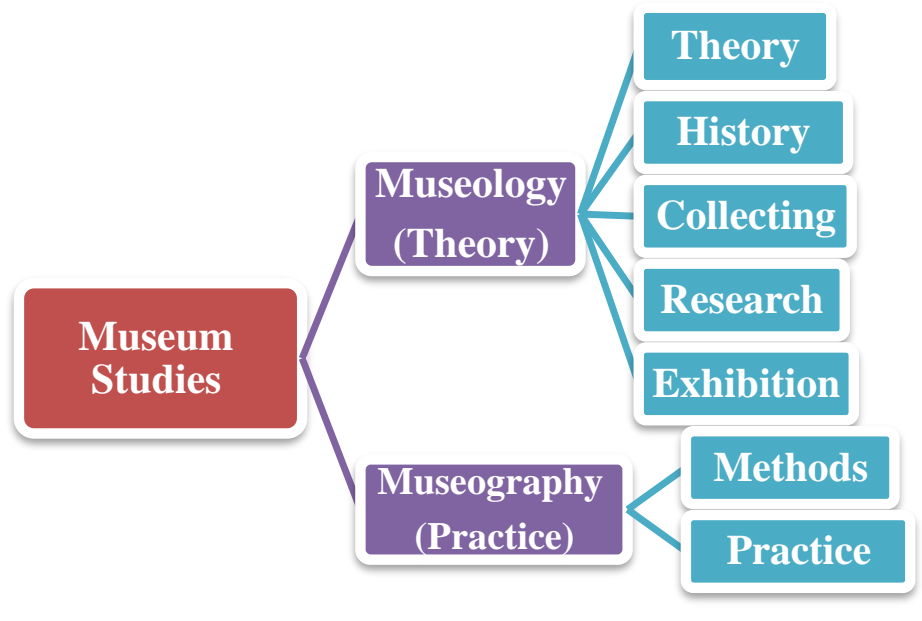


The constant challenges that the museum studies programs confront are related to the variable learning needs, professional expectations, and evolving technological instructional strategies (Davis, 2005). According to Williams and Simmons standards for museum studies programs are very essential. The first step toward these standards is to define the required courses for the program in accordance with the expectations of the museum field, intended audience, purpose of the course, and possible prerequisites (Williams and Simmons, 2006). The program should contain competencies that related to all functional areas of the museum including collections, management, capacity building community connections and internships. Collections include: refinement, research and publication, preservation (storage and handling). Management includes the number of activities involved with the institutional stability and vision including finances and non-profit administration, leadership (staffing, planning) and governance (facility maintenance, safety and security). Capacity building includes message of the institution, developing and establishing resources needed for museum to move forward (donor cultivation, grant writing, membership, retail and earned income) and supporters (coordination with governmental and nongovernmental entities). Community connections include communications (museum's programs to different audiences), marketing and public relations, outreach, publications, and evaluation. Interpretation includes all of the means and media through exhibits and programming, exhibition design, object research, (Welsh, 2012) (fig.2).

Fig.2 Functions of the museum in the museum studies contents, inspired from (Welsh, 2012)

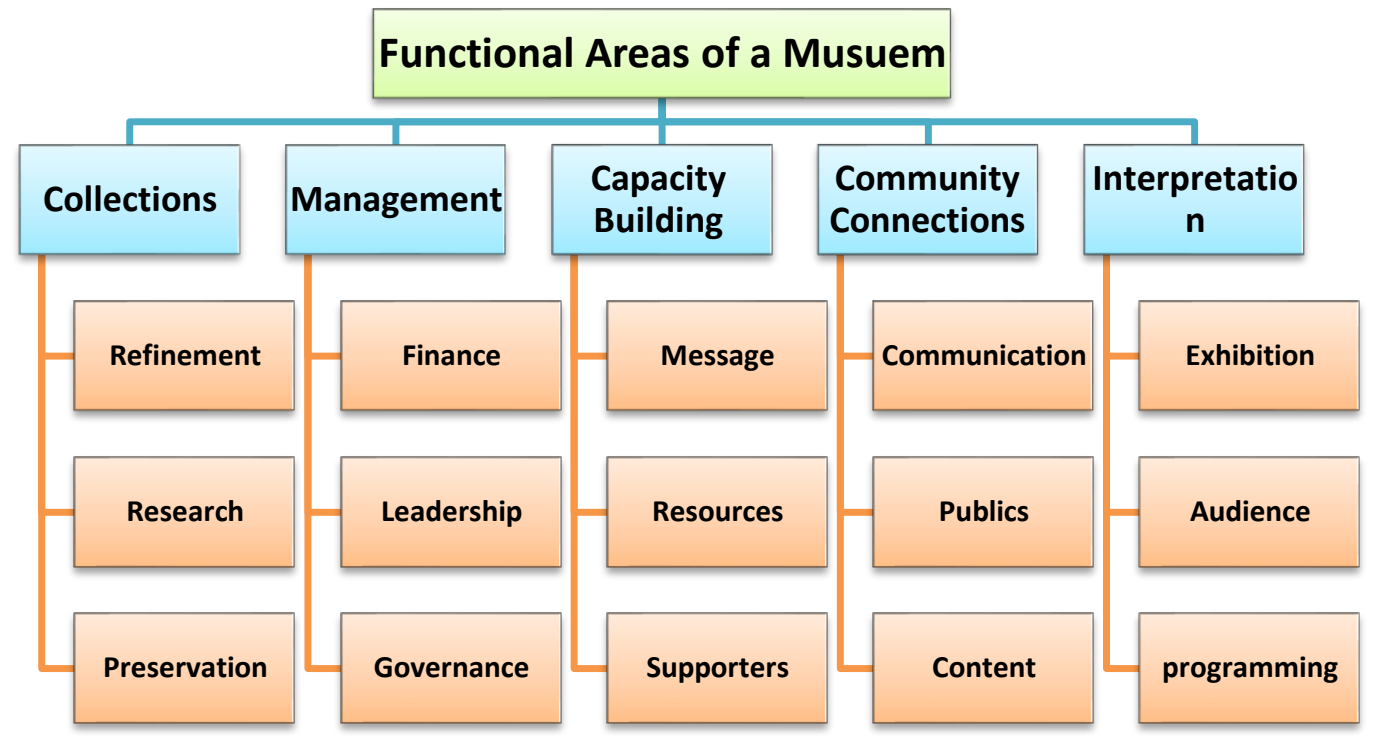

Fig.2 Functions of the museum in the museum studies contents, inspired from (Welsh, 2012) The International Council of Museums (ICOM)'s International Committee for the Training Personnel (ICTOP)'s main focus is to promote museum education and training. It listed a number of suggested curriculum topics subdivided into 5 competencies "general", "museology", "management", "public programming", and "information and collections management and care". Each is supplemented with additional topics arranged in multi-tiered system (Williams and Simmons, 2006). The ICOM also developed in 2000 curriculum guidelines for programs of museum studies; describing five main competencies related to specific areas including management, public programming, museology, information and collections management and care (Duff and others, 2010) 
The AAM (American Association of Museums founded in 1906) reported that museum studies should be a graduate program with collaboration of one or more museums within the geographical proximity of the university. The program should be based on relevant academic discipline like archaeology, art history and history. The program should include at least 6 credit hours for museum history, theory and practice. Program must have at least one person designated as museum coordinator or director. The faculty should possess substantial museum work experience and appropriate academic degree with a period of at least two academic years including a supervised museum internship (AAM Museum Studies Committee, 1978; American Association of Museums Professional Practices Committee, 1983). The AAM Museum Studies Curriculum Committee issued a guide with the title Museum Studies: A Curriculum Guide for Universities and Museums in 1973 as standard curriculum. The same committee issued another standard for the core of the curriculum to include certain topics (AAM Museum Studies Committee, 1978) which have become the core of all museum studies programs in U.S as follows:

- History, philosophy and purposes of museums

- Professional ethics.

- Management of collections, acquisition, conservation and documentation.

- Utilization of museum objects in research, education and interpretation.

- Exhibition planning and design.

- Evaluation of the visitor experience.

- Administration of finances, personnel, public relations and physical facilities.

- Internship.

Criteria were made by a subcommittee of the AAM in 1983 to examine the feasibility of accrediting graduate museum studies named "Criteria for examining Professional Museum Studies Programs". The criteria include goals and Objectives, curriculum, faculty, students, governance and administration, (American Association of Museums Professional Practices Committee, 1983). For Goals and objectives, they should meet the qualifications of the university and museum and reflect the standards in policy statements of the AAM. The curriculum should contain knowledge of theory and practice of museology and museography. The faculty should be experienced in professional museum practices and representative of the academic disciplines appropriate to its scope. The students should be of highest quality and commitment to the museum field and admission should be limited to those who hold a bachelor's degree in a discipline relevant to the objectives of the program. For the governance, the program should be administrated in a way that ensures achievements of its objectives. Finally, the administration of the program should provide an environment in which the research, teaching and learning activities of faculty and students are encouraged (American Association of Museums Professional Practices Committee, 1983).

All museum studies programs have internship often addressed to only one particular type of museum work as "hands-on experience". In some programs, students are expected to find their own internships. However, the program directors work closely with the museums to establish working relationships (Spiess II, 1996). As a matter of fact, these sorts of learning partnerships enable students to undertake work-based assignments focused on museum issues which can encourage the learners to comprehend real-life issues within the framework of academic courses (Davis, 2005). The supervised internship is essential of any museum studies program and should be at least 6 months in which interns should be treated as a staff member with a full-time employment and supervised by the museum staff members. At the conclusion of the internship, 
reports should be prepared by both the interns and the supervisors, and evaluation should be made with reference to criteria set ahad (Report of AAM Museum Studies Committee, 1978). Programs of museum studies in the United States of America are multidisciplinary developed by universities in consultation with professionals of museums in order to graduate people to work in museums. They vary in degrees, disciplinary, and requirements (American Association of Museums Professional Practices Committee, 1983; Williams and Simmons 2006). According to Williams and Simmons, there are five trends of standardized curricula of programs of museum studies in U.S. as follows:

- An introductory course: philosophy, history, functions, purpose, structure, operations, and vocabulary of museum field.

- Secondary courses: functions of museums, including museum administration, collection, operations (management, care, and use) and public service.

- Recognition of competencies in terms of knowledge, skills, and attributes.

- Recognition of shared and functional competencies.

- Application of a hierarchical system of topics for communicating organization and structure of curricula (Williams and Simmons, 2006).

In addition, they made a model of four levels as a standard curriculum for museum studies as follows: Level one with the course "Introduction to Museum Field" appropriate for any individual to prepare students for the courses of the second level. Level two is structured competencies required for career-oriented individuals. The courses however are general not specialized but provide the learner an understanding and appreciation for the museum field. Level three is about important standard functions and applies only to the career-oriented museum workers; specialized for specific areas of administration, collections, or public service. Level four includes non-museum courses important to specialized functions in museum field like art history, natural history and material culture (Williams and Simmons, 2006).

\section{Program Specification of the MHS}

The research uses the approach of "case study" of the program of the Museum and Heritage Studies of the University of Denver (DU), Colorado and "analytical study" of all its components: curricula, courses, syllabi and instructional strategies in seeking to achieve the research objectives; and data is collected through semi-structured interviews addressed to students and professors of the program.

The Museum and Heritage Studies (MHS) Program is a master degree in Anthropology with a concentration program in the Department of Anthropology. The first course in museum studies was introduced by Arminta Neal introduced in 1949 and in 1989, the department restructured the museum and heritage studies concentration. The department embraces its own museum known as the University of Denver Museum of Anthropology which includes archaeological and ethnographic collections of approximately 165,000 objects in the collections, used for teaching, research, and exhibition as well. In addition, students in the Museum Studies program work in the museum and gallery to gain experience in registration, collections management, conservation, exhibit development, grant writing, long range planning, event planning, and educational outreach (Museum and Heritage studies Handbook).

The program emphasizes:

- critical, reflexive, and culturally appropriate museology

- the history and philosophical underpinnings of museums and their roles in society 
- cross-cultural approaches to museums and curatorial work

- community-based as well as international/global perspectives

- public, applied, and engaged anthropology (Web page of the program)

Museum and Heritage Studies is a two-year program designed to provide students with a background of the theoretical and academic, as well as the practical and professional aspects of museum and heritage studies. The total credits for the degree are 48. The requirements of the program are theoretical 4 courses with 16 credits an must include one of the following: Critical Perspectives in Museum and Heritage Studies, Museum Anthropology or Archaeological Method and Theory, 3 practice-oriented courses with 12 credits like Museums and their Visitors, Introduction to Conservation. Museum Exhibit Development, Managing Collections, Applied Heritage Management and Museum Practicum, 3 more elective courses with 12 credits and 2 extra courses taken in or outside the department so students may take from other departments or internship with 8 credits in addition to thesis or paper. Students are required to attend department colloquia, gallery openings and talks. The program also allows students to complete a supervised museum internship an integral part, usually consisting of a minimum of 120 hours of work. At least two quarters of museum studies courses must be completed before beginning an internship

\section{Internship}

The students are required to have supervisors that should be employees and professional staff members of the institution in which the students work. The director of the program sends the supervisors a letter explaining procedures and a copy of the "Museum Intern Agreement" form. For assessment, they are done by the supervisors twice through two reports (fig.3): "Supervisor's Mid-Term Report" and "Final Evaluation of Internship and Intern" at the appropriate times. At the beginning of the internship each student should prepare a contract between with his/her supervisor stating the beginning and ending dates of the internship, the number of hours he/she will work per week as well as a tentative schedule; job duties or tasks to perform, and the learning objectives. This contract should be submitted to director of program. Students are required to submit biweekly reports to the director describing the activities and progress. Final assessment of the internship is based on the students' final reports (as evaluation of their internship experience describing the activities and the work they accomplished as well as your success in meeting their learning objectives) and the supervisor's evaluation of their performance.

Fig.3 Forms of Student's Bi-Weekly Report and the Supervisor's Final Evaluation

Intern's Name:
Intern's Home Phone:
Date:
1. Briefly summarize the last two weeks' activities:
2. Are you satisfied with your internship training to date?
3. Do you have any suggestions as to how your internship might be improved?
4. Is there anything that the DU Museum Studies program can do to assist you during
the next two weeks?
5. Other comments?
Please return to: Dr. Christina Kreps, Department of Anthropology, 2000 Asbury, Sturm
146 S, University of Denver, Denver, CO $80208-2406$

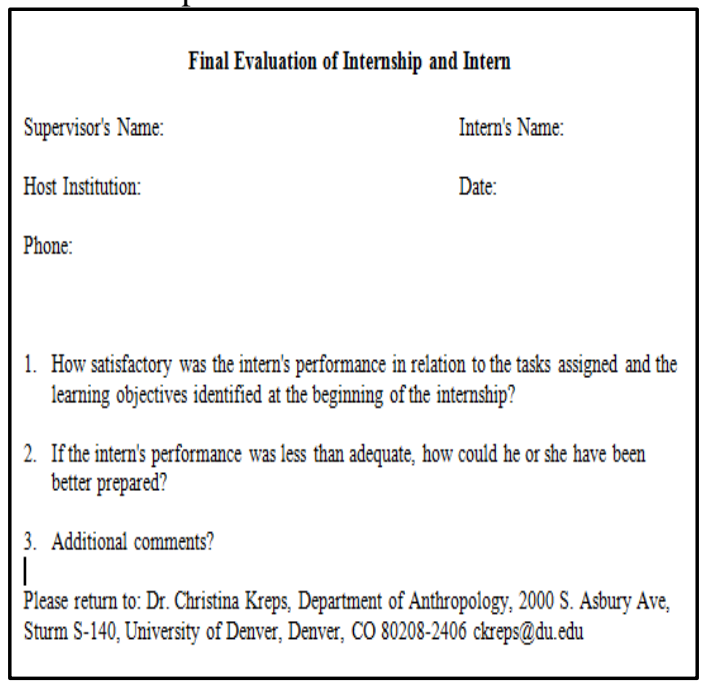




\section{Syllabi and Teaching Strategies}

\section{a) Syllabi}

The number of the compulsory and elective courses of the program of Museum and Heritage Studies offers is 28 . The number of the faculty members who teach in this program is 4 . They were very cooperative and provided the syllabi of the courses they teach in order conduct the research.

The main items of all the syllabi are:

- Introduction or a course description: a summary of course's subject and its main aim.

- Main course objectives written in points or paragraphs including the procedures used to achieve them

- Learning outcomes: varying from 2 to 7 outcomes

- Requirements of the course: including field work, participation, writing and research.

- Grading matrix in percentage of the student work and assessments in some syllabi with few details about the assignments and the student works)

- Schedule of the topics of the courses

- Mandatory readings: varying from 1 to 12.

- Optional readings: varying from 1 to 21.

Items found in some of the syllabi.

- Schedule for activities and seminars related to the course.

- Perquisites (if required)

- Office hours

- Equipment lists if the course's requires field works.

- Accommodations: information of the accommodation the program provides for the students in the field works

\section{b) Teaching Strategies and Methods}

The findings of the teaching strategies and methods used in classes were reached by two ways: attending some classes with students (fig.4) and interviewing four out of the five members of the faculty of the program. The major result is that all the teaching strategies focus on researching, writing and projects. Certain methods use in all the courses, while some were used only in some of them.

The main teaching and learning methods used in all the courses:

- Lecturing (using presentations and videos)

- Open discussions

- Grouping workshops

- Writing papers and reviews.

- Readings

Some teaching and learning methods used in only in some courses:

- Case study

- Projects and reporting

- Museum visits

- Practicing in field work (courses related to archaeology) 
Fig.4 Attending classes and museum visits
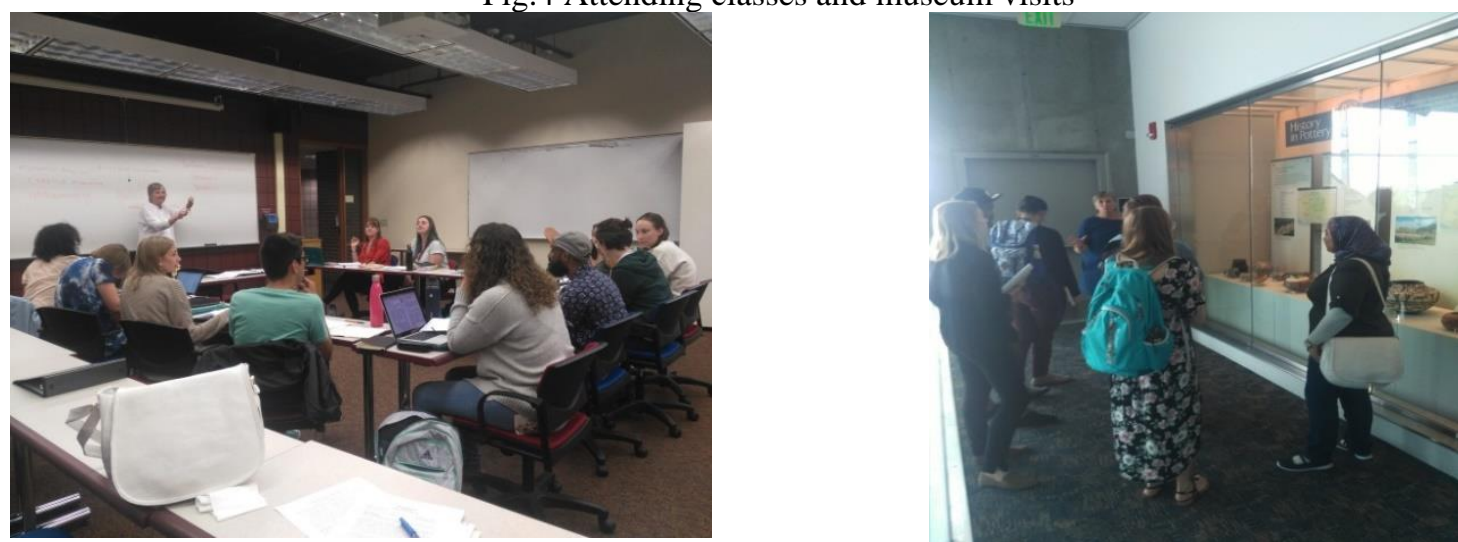

(Taken by the researcher during the Fulbright grant, 2018)

\section{Methodology}

The study adopted the "case study" approach through Using:

1- Participant observation, which is preferable to use in descriptive studies, especially those related to the elements of the societies culture, as it contributes to a more accurate analysis of the phenomenon because it includes the researchers' experience of the research community directly and closely.

2- Two semi-structured interviews were used by preparing a list of questions in advance, the first one was directed in the same order to 13 out of 16 students (6 of the first year and 7 of the second year) using open ended questions related to the personal data of the sample members and the areas of the study. Response rate was $81 \%$.

The questions were divided into two categories:

Category (A) about joining the Master Program of Museum and Heritage Studies at DU

1. Year of graduation and major

2. Goals of joining the program.

3. Reasons of choosing the DU program.

Category (B) about the Expectations and Career

1. Previous experience in field before joining the program.

2. Expectations before joining the programs.

3. How the program and its courses affected career plans (for second year students)

The other list of questions was addressed to the professors about teaching strategies and methods and was directed to 4 out 5 professors, response rate was $80 \%$ (varying from lecturers, associate professors and professors). The study was during the Fulbright grand four-month period, and each interview lasted about 30-45 minutes.

\section{Results and Discussion}

Category (A) about joining the Master Program of Museum and Heritage Studies at DU

1- The graduation years of the first and second year students are within 2012-2018. The major study of the majority is anthropology with art history, philosophy, sociology library or western English minors. The main major of the students' graduation: 10 of the students with percentage of 76.9 graduated with the major of anthropology, 1 with percentage of 7.7 with media arts, 1 with percentage of 7.7 with art history, 1 with percentage of 7.7 with library and information sciences.

2- Goals of studying the program: The first goal of all the students is to work in a museum with percentage of $100 \%$, The majority's second goal, 11 students with percentage of 84.6 
is to gain knowledge and skills of museums including curation, collections and exhibits management, education, and preservation, the third goal of 2 students with percentage of 15.4 is learning about research skills.

3- All the students with percentage of $100 \%$ agree that they joined the DU program because it combines anthropology discipline with museum. 8 students with percentage of 61.5 agree that one of the reasons of choosing this program is the professors who teach, especially Professor Christina Kreps the director of the program, as she has a great biography and a many resarches in the field of museum and cultural heritage. 6 of the students with percentage of 46.2 choose the program because it is theoretical and critic, 5 with percentage of 38.5 choose it because the program provides opportunities for work after graduation and 3 with percentage of 23.1 joined the program because it is in Denver which has many museums and galleries.

It is obvious that the students who prefer to join the master program of museum and heritage studies at DU is of anthropology major and the main goal of all of them is to work in museums. The other goals of the students relate to working in museums as well like gaining knowledge of museums and research skills. It is also interesting that one of the main factors that motivate students to join the program is the professors that should have experience and knowledge of the field.

Category (B) about the expectations and career

1. The majority of the students; 8 students with percentage of $61.5 \%$ were volunteers in museum ranging between one and two years before joining the program at the DU. 3 students with percentage of $23.1 \%$ reported that they had taken internships and 2 with percentage of $15.4 \%$ had the opportunity to have a summer student employment at museums before joining the program. All students with percentage of $100 \%$ agree that they enjoyed these experiences which made them more interested in museum studies.

2. The main expectations of all the students with percentage of $100 \%$ before joining the program was to have more knowledge about museum and cultural heritage studies and all its functions. Only 2 students with percentage of $15.4 \%$ added a second expectation related to learning skills of research.

3. 5 of the students with percentage of $38.5 \%$ are completely satisfied with the program with its courses and contents; 7 are quite satisfied with a percentage varying $53.8 \%$ and 1 is less satisfied with a percentage of $7.7 \%$.

4. All the students with percentage of $100 \%$ agree that the courses and the contents affected their plan of future positively. They all now know after studying the program what kind of work and position they want to have in museums or non-profit cultural heritage organization;

5. 1 student with percentage of 7.7 wants to continue a $\mathrm{PhD}$ study and to be a professor in the field.

- The program of Museum and Heritage Studies at the University of Denver is a disciplinebased and non-degree granting with museum studies as a supplement. The degree comes from the subject department which is anthropology.

- The courses can be divided into two categories: theoretical and practical.

- The internship is an essential requirement of the program with evaluation provided by both the supervisors (employees in museums or heritage institutions) of the students and the students themselves.

- Syllabi include all the required items of the courses according to their natures. 
- There are 9 teaching strategies: 5 of them used are common in all the courses an 4 are variable according to the type of the courses

- The interviews findings indicate that the main target of such program is to work in museums or nonprofit cultural institutions which are seen a good working environment. Moreover, the answers of the students indicate advantages of the program like offering internships and work opportunities later and give support to the students to build professional networks, having professors of great knowledge and very experienced in the field of museums and cultural heritage and that the program provides all the required knowledge and skills for museum professionals. On the other hand, some students see a number of negative points of the program like being too theoretical and need more practical parts. In addition, some students expressed their desire to have a $\mathrm{PhD}$ degree in the cultural heritage to acquire advanced knowledge of the field and be professors.

\section{Suggested Framework of a Cultural Heritage Program in Egyptian Tourism Education}

The following is a suggested framework of a cultural heritage program in Egyptian tourism educational institutions, tourism guidance discipline-based:

- It should be a post-graduate program; Master's degree is more favorable for the present time.

- The faculty should have good extent of experience in museum and cultural heritage field including researches, conferences and other participations of the staff members.

- The curriculum must contain the following competencies:

- Skills of research, education, and interpretation.

- Administration of finances, personnel, public relations, and physical facilities.

- Theory, history, and philosophy of museums

- Functions of museums (Management of collections, acquisition, Exhibition planning, design. conservation and documentation).

- Internship, which must be at least 6 credits undertaken through collaboration with museums or relative cultural heritage institutions and regional associations in the same vicinity of the educational institution.

- The curriculum's goals should find balance between theory and practice, meet the needs of the students and prepare them to be future leaders (Welsh, 2012)

- Adopting innovative teaching and learning methods using ICT (Information and Communication Technology), especially that many museums and cultural institutions all over the world have created special electronic archives for their collections and libraries (Ott and Pozzi, 2011).

- It is important that program can also offer conferences, colloquia and workshops of expertise in the field in order to provide the students with all their experience and knowledge of the field including the challenges and problems which the sector of cultural heritage confronts.

\section{Conclusions}

There is a close link between cultural heritage and tourism as cultural heritage can be a great source of economic development through heritage tourism which has grown rapidly. People of different cultures tempt to know more about each other; and have the opportunity to practice each other's habits and customs. Tourism on one hand plays a major role to increase the employment rates, provide foreign currencies, create more job opportunities; on the other hand tourism enhances the utilizing of both tangible cultural heritage represented by historical sites and 
buildings; and intangible cultural heritage reflected in the different manifestations of habits and traditions of the people of the tourist destination. Tourism has played an important role in the affirmation of the importance of cultural heritage. The local communities can benefit from tourism directly and indirectly: directly by selling services, commercial articles and traditional crafts to tourists, and indirectly by receiving improvements in the infrastructure, conservation of some historic sites and urban rehabilitation. Thus, cultural heritage's uniqueness is an international competitive advantage, and should be utilized as an economic potential demands development.

Egypt owns great legacy of tangible cultural heritage (monuments, archaeological and historical places, museums, artifacts, etc.) and intangible cultural heritage (customs, traditions, skills, expressions, etc.), which represent significant tourist attractions. This indicates the importance of preserving it in the tourism. However, cultural heritage in tourism education in Egypt does not exceed the study of a few courses and two master programs of the Faculty of Tourism and Hotels, Helwan University: one is the program of Museum Studies and the other is the program of Heritage Conservation and Site Management. Therefore, there is an urge need to establish more cultural heritage programs in tourism educational institutions; particularly universities in order to be in line with the importance of the Egyptian cultural heritage. Recently, some universities of which Alexandria University is one of; realized the importance of this type of study and started to plan to develop programs of cultural heritage studies. Greater efforts still must be made in this area.

In Egypt today the majority of the professionals in museums and relevant cultural heritage institutions did not graduate with a museum or cultural heritage discipline degree. They more or less have gained their knowledge and skills through their graduate studies in traditional disciplinary areas and their degrees come from subject departments like archaeology, history, tour guiding, administration management and ...etc. This has been satisfactory approach for years. However, it has become a necessary to give up this approach since museology and cultural heritage studies have become a discipline science implemented and developed in many parts of the world. It is time to have people with a museum or cultural heritage discipline degree provided with the required competencies and skills to work in Egyptian museums and cultural heritage institutions.

Tour guides are an important tool for introducing cultural heritage, as they are responsible for interpreting the cultural heritage to the tourists and provide them with the necessary information. Therefore, it is important for them to understand and be aware of all cultural heritage of their country and should be provided with the knowledge and training to be able to do that effectively. Therefore, departments of Tourism guidance can be an excellent academic incubator of a program of cultural heritage and museum studies. It is more recommended to be a tourism guidance discipline-based master degree with the possibility of providing a $\mathrm{PhD}$ degree in future with the growing awareness of the importance of this type of studies.

The example of the program of Cultural Heritage and Museum Studies of the University of Denver can be a good benchmark for objectives of the program, certain courses, teaching strategies and internship in order to start to develop similar programs in the Egyptian education taken into account the differences of culture and the disciplines (of anthropology in the University of Denver and tourism guidance in Egyptian education).

\section{References}

American Association of Museums Professional Practices Committee. (1983). Criteria for examining professional museum studies programs. Museum News 61(2), 70-71. 
Borissova, Vladia. (2018). 'Cultural Heritage Digitization and Related Intellectual Property Issues'. Journal of Cultural Heritage, 1-6.

Bouchenaki, M., b2003). 'The Interdependency of the Tangible and Intangible Cultural Heritage', communication inaugural/ Keynote address, ICOMOS $14^{\text {th }}$ General Assembly and Scientific Symposium, Place-Memory-Meaning: Preserving Intangible Values in Monuments and Sites.

https://pdfs.semanticscholar.org/baa9/83afa9412875f7732ac1652d4834b5ea854a.pdf last access $\underline{13 / 9 / 2018 .}$

Buckland, M., (2013), 'Cultural Heritage (Patrimony): An Introduction', Records, Achieves, and Memory: Selected Papers from the Conference and School on Records, Archives and Memory Studies, University of Zadar, Croatia,May 2013, Willer, M., Gilliland, A. and Tomić, M., (Eds.), University of Zadar, pp.11-25.

Chhabra, D., Healy, R., and Sills, E. (2003). 'Staged Authenticity and Heritage Tourism'. Annals of Tourism Research, 30(3), 702-719.

The Contribution of education to Cultural Development. (1992).Report of UNESCO

International Conference on Education 43 ${ }^{\text {rd }}$ Session, (14-19 September, 1992), 12

Cormack, P.(1976) Heritage in Danger, London: New English j.

Corsane, G. (2005) "Issues in Heritage, Museums and Gallaries: a brief Introduction" in

Heritage, Museums and Gallaries: an Introductory Reader, Ed. G. Corsane: London and New York: Routledge, 1-12.

Davis, Joy. (2005). 'Responding to Change: Challenges for Professional Education in the Museum Sector'. Curator: The Musuem Journal 48 no. (4), 427-438.

Duff, Wendy M, Cherry, Joan M. and Sheffield, Rebecka. (2010). 'Creating a Better Understanding of who we are: A Survey of Graduates of a Museum Studies program'. Museum Management and Curatorship 25:4, 361-381.

Graham, B., Ashworth, G. J., and Tunbridges J. E., "The Uses and Abuses of Heritage", in Heritage, Museums and Galleries: an Introductory Reader, Ed. G. Corsane: London and New York: Routledge, 26-37.

Gravari-Barbas, Maria. (2018). 'Tourism as Heritage Producing Machine'. Tourism management Perspectives 26, 5-8.

Gruber, M., (2009), 'The Role of E-learning in Arts and Heritage Education', In V. HornungPrähauser\& M. Luckmann (Eds.), Kreativität und InnovationskompetenzimdigitalenNetzCreativity and Innovation Competencies in the Web, Sammlung von ausgewählten Fachund Praxisbeiträgen der 5. EduMediaFachtagung 2009, Salzburg, pp. 343-350.

Hansen, A., (2014), 'The Heritage Learning Framework and the Heritage Learning Outcomes', in Christidou, D. (Ed.), Implementing heritage Outcomes, Frvårdaren 37, Östersund, 7-24.

Hawks, C. A. and Goldsmith, D. F. (2006) 'Occupational and Environmental Health education for Musuem Professionals', in Musuem Studies: Perspectives and Innovations (Ed.)

Williams, S. L. and Hawks, C. A., Society for the Preservation of Natural History Collection, Washington D.C., 151-160.

Higginbottom, G., (2014). 'Intangible Cultural Heritage', in Smith, C. (Ed.). Encyclopedia of Global Archaeology. Springer Reference, 3918-3921.

ICOM Training Unit (1972), Professional Training of Museum Personnel in the World: Actual State of Problem, Paris.

ICOM Development of the Museum Definition according to ICOM Statutes (2007-1946) http://archives.icom.museum/hist_def_eng.html, last access 17/11/2018 
2011 International Conference on Telecommunication Technology and Applications Proc .of CSIT vol.5 (2011), 177-182.

Kearney, A., (2009), 'Intangible Cultural Heritage: Golbal Awareness and Local Interest', in Smith, L. and Akagawa, N. (Eds.), Intangible Heritage, London and New York, pp.209226.

Keough, E. B., (2011), 'Heritage in Peril: A Critique of UNESCO's World Heritage Program', Washington University Global Studies Law Review 10, issue 3, pp.593-615.

Kurniawan, Heri, Salim, Agus, Suhartanto, Heru and Hasibuan, Zainal. (2011). 'E.Cultural Heritage and Natural History Framework: An Integrated Approach to Digital Reservation'. 2011 International Conference on Telecommunication Technology and Applications Proc of CSIT vol.5 (2011) Singapor. 177-182.

Latham, Kiersten F. and Simmons, John E. (2014). Foundations of Museum Studies: Evolving systems of knowledge. Santa Barbra, Denver and Oxford.

Macleod, Suzanne. (2001). 'Making Musuem Studies: Training, Education, Research and Practice', Museum Management and Curatorship 19 no.1, 51-61.

Mendoza, Raynel, Baldiris, Silvia and Fabregat, Ramon. (2015). 'Framework to Heritage Education Using Emerging Technology', Procedia Computer Science 75, 239-249.

Museum and heritage Studies Handbook, 1-14

https://www.du.edu/ahss/anthropology/media/documents/mhshandbook1718.pdf, last access $18 / 11 / 2018$.

Ocal, T. (2016). 'Necessity of Cultural Historical Heritage Education in Social Studies Teaching', Creative Education, 7(03), 396-406.

https://file.scirp.org/pdf/CE_2016031415590861.pdf, last access 16/11/2018.

Ott, Michela and Pozzi, Francesca. (2011), 'Towards a New Era for Cultural Heritage Education:

Discussing the Role of ICT', Computers in Human Behavior 27, 1365-1371.

Petr, Christine. (2015). 'How Heritage Site Tourists may become Monument Visitors'. Tourism

Management 51, 247-262.

Petronela, Tudorache. (2016). 'The importance of the Intangible Cultural Heritage in the Economy'. Procedia economic and Finance 39, 731-736.

Pozzi, Francesca and Dagnino, Francesca. (2018). 'Editorial. Educational Technology and Tangible-Intangible Cultural heritage'. Italian Journal of Educational Technology, 3-4.

AAM Museum Studies Committee. (1978) 'Museum Studies' Museum News 56 November/December, 19-26.

Rodzi, Nur, Zaki, Saniah and Subli, Syed. (2013). 'Between Tourism and Intangible Cultural Heritage'. Procedia: Social and Behavioral Science 85, 411-420.

Simmons, J. E. (2006) 'Museum Studies Programs in North America', in Musuem Studies: Perspectives and Innovations (Ed.) Williams, S. L. and Hawks, C. A., Society for the Preservation of Natural History Collection, Washington D.C.,113-121.

Šola, T. (1982) 'A Contribution to a possible Definition of Museology" in Interdisciplinary in Museology, MuWoP, Paris.

Spiess II, P. D. (1996) 'Museum Studies: Are They Doing their Job?' in Museum News 75(6), 32-40.

Starn, Randolph, (2005), "A Historian's Brief Guide to New Museum Studies", in American Historical Review, 68-98. 
Stone, P. (2005) 'Presenting the Past: A Framework for Discussion', in Heritage, Museums and Gallaries: an Introductory reader, Ed. Gerard Corsane, Routledge London and New York, 2005, 215-227.

Theather, J. L. (1991) 'Musuems Studies: Reflecting on Reflective Practice', Museum Management and Curatorship 10, 403-417.

Timothy, D. J., and Nyaupane, G. P. (Eds.). (2009). Cultural Heritage and Tourism in the Developing World: A Regional Perspective. Routledge.

UNESCO Basic Texts of the 1972 World Heritage Convention 2005 edition, UNESCO World Heritage Center

http://whc.unesco.org/uploads/activities/documents/activity-562-4.pdf

http://whc.unesco.org/uploads/activities/documents/activity-562-4.pdf,(last access $16 / 11 / 2018$.

UNESCO (2005) Basic Texts of the 1972 World Heritage Convention, Paris.

http://whc.unesco.org/uploads/activities/documents/activity-562-4.pdf, last access 13/9/2018.

UNESCO, (2011). Culture and Development, in UN. General Assembly 66 ${ }^{\text {th }}$ session, A/66/187.

UNESCO (2016) Basic Texts of the 2003 Convention for the Safeguarding of the Intangible Cultural Heritage, Paris

https://ich.unesco.org/en/news/2016-edition-of-the-basic-texts-published-00208, last access $16 / 11 / 2018$.

Vecco, M. (2010). 'A Definition of Cultural Heritage: From the Tangible to the Intangible. Journal of Cultural Heritage, 11(3), 321-324.

Williams, S. L. and Simmons, J. E. (2006) 'Curriculum Standards for Museum Studies Programs' in Museum Studies: Perspectives and Innovations (Ed.) Williams, S. L. and Hawks, C. A., Society for the Preservation of Natural History Collection, Washington D.C., 129-149.

https://www.du.edu/ahss/anthropology/programs/graduate/museumstudies.html, last access 20/11/2018. 